\title{
Assessment of Nutrient Intakes: Introduction to the Special Issue
}

\author{
Sharon I. Kirkpatrick ${ }^{1, *}$ and Clare E. Collins ${ }^{2, *}$ \\ 1 School of Public Health and Health Systems, University of Waterloo, Waterloo, ON N2L 3G1, Canada \\ 2 Priority Research Centre for Physical Activity and Nutrition, School of Health Sciences, \\ Faculty of Health and Medicine, University of Newcastle, Newcastle, NSW 2308, Australia \\ * Correspondence: sharon.kirkpatrick@uwaterloo.ca (S.I.K.); clare.collins@newcastle.edu.au (C.E.C.); \\ Tel.: +1-519-888-4567 (ext. 37054) (S.I.K.); +61-02-4921-5646 (C.E.C.)
}

Received: 15 March 2016; Accepted: 21 March 2016; Published: 25 March 2016

Accurately measuring consumption of food, drinks and supplements is fundamental to nutrition and health research, including surveillance, epidemiology and intervention studies. However, assessing food intake is an area that is fraught with challenges [1]. Diet is inherently complex given that it is a chronic and multifaceted phenomenon that changes over time and varies in relation to age, life stage and many other factors. The challenges associated with assessing diet and nutrient intakes have led to the productive area of research that is the focus of this issue of Nutrients.

Usual diet, or long-term average diet, is the phenomenon typically of interest in nutrition and health research. However, objective measures of usual diet are few and can be of limited use, while carrying high costs and substantial researcher and respondent burden [2,3]. As a result, researchers typically rely on self-report measures, such as 24 -h recalls, food records, food frequency questionnaires, and brief instruments. The extent of error in dietary data collected using self-report instruments and tools has recently been debated [4-9], with some critics suggesting that such data be abandoned. However, this error and its implications for interpreting the findings from nutrition research have long been recognized. Indeed, nutritionists, statisticians and epidemiologists in various parts of the world have made important advances over several years to better understand measurement error within self-reported dietary data and to identify ways to address it. These advances have included the use of recovery biomarkers, which provide an objective measure of true intake for energy and a few nutrients, to ascertain the types and degree of error affecting data collected using different types of instruments, e.g., [10,11]. The findings of biomarker-based studies have informed recommendations for measuring diet in different types of studies, e.g., [1] and the development of statistical methods that allow for adjustment for error, e.g., [12-16]. There has also been work to combine concentration biomarker and self-report data to mitigate measurement error, e.g., [14,17]. Further, the evolving understanding of limitations of existing tools combined with technological advances have enabled a new generation of dietary assessment instruments and strategies, including web-based tools, mobile apps, and image-based assessment, which are aimed at mitigating some of the challenges of traditional methods and modes of data collection [3].

This Special Issue of Nutrients provides examples of the diversity of research that is underway internationally to advance the robust collection and use of dietary data. The issue encompasses 27 articles (18-44), with contributions from Australia, Brazil, Canada, Guam, Japan, Russia, South Korea, the United Kingdom, and the United States, as well as several countries in the European Union. The range of articles included demonstrates efforts being made to improve the quality of dietary data collected from populations across the lifecycle and across contexts, with applications related to characterizing dietary intakes, as well as associations between diet and health. Articles in this issue describe the development and/or evaluation of new tools [18-27], some of which take advantage of technology to address limitations in existing tools. Among these are mobile phone instruments $[21,22,25]$, including a novel tool that incorporates not only health but also sustainability 
considerations related to diet [23], as well as a web-based 24-h recall developed in the UK [24]. The use of biomarkers to assess intake and to evaluate self-report tools is also highlighted. For example, Tasevska examines the evidence to support the use of urinary sugars as a biomarker for total sugar intake [28], Lai et al. examine the use of biomarkers to assess the validity of a food frequency questionnaire [20], and Zheng et al. explore the potential of metabolomics as markers of intake [29].

The issue also highlights efforts to better understand the optimal use of existing tools. For example, Kerr et al. examine whether accuracy of recall among adolescents improves with a second administration of a 24-h dietary recall [30]. Of interest in terms of understanding the comparability of data generated by surveillance systems in different countries, De Keyzer et al. [31] provide a narrative review of methods used to assess diet in national food consumption surveys across continents. Such reviews and consideration of their findings are increasingly important as it is recognized that inconsistency in assessment methods complicates the interpretation of the larger evidence base, as well as posing a barrier to efforts to conduct pooled and cross-country analyses. Statistical methods for estimating usual intake of dietary components are also addressed, with a comparison of methods undertaken by Laureano et al. [32]

Finally, applied papers demonstrate the ways in which existing methods and resulting data contribute to our understanding of diet among populations [33-40], as well to the evaluation of interventions [41]. Papers within this issue also address dietary patterns and diet quality indices [42-44], growing areas within nutrition research as the importance of embracing the complexity of what we eat and drink is increasingly recognized.

This collection of papers demonstrates that dietary assessment research is alive and well. The advances in the use of technologic innovation and biomarkers to enhance measures of diet have the potential to contribute to the collection of higher quality data in future research. This issue of Nutrients also provides an opportunity to consider gaps in the evidence base on the assessment of diet and future research directions that could potentially benefit from a more collaborative approach. Working together across institutions and countries can provide researchers with the opportunity to learn from one another, as well as to leverage scarce resources to advance the field.

Acknowledgments: Sharon Kirkpatrick is funded by a Canadian Cancer Society Research Institute Capacity Development Award (grant \# 702855). Clare Collins is supported by a National Health and Medical Research Council of Australia Senior Research Fellowship. The authors are grateful to Amanda Raffoul at the University of Waterloo for her assistance with referencing.

Conflicts of Interest: The authors have no conflicts of interest to declare.

\section{References}

1. Thompson, F.E.; Kirkpatrick, S.I.; Subar, A.F.; Reedy, J.; Schap, T.E.; Wilson, M.M.; Krebs-Smith, S.M. The National Cancer Institute's Dietary Assessment Primer: A resource for diet research. J. Acad. Nutr. Diet. 2015, 115, 1986-1995. [CrossRef] [PubMed]

2. Applied Research: Cancer Control and Population Sciences. Measurement Error Webinar Series. Available online: http:/ /appliedresearch.cancer.gov/measurementerror/ (accessed on 28 July 2015).

3. Thompson, F.E.; Subar, A.F.; Loria, C.M.; Reedy, J.L.; Baranowski, T. Need for technological innovation in dietary assessment. J. Am. Diet. Assoc. 2010, 110, 48-51. [CrossRef] [PubMed]

4. Archer, E.; Hand, G.A.; Blair, S.N. Validity of U.S. nutritional surveillance: National Health and Nutrition Examination Survey caloric energy intake data, 1971-2010. PLoS ONE 2013, 8, e76632. [CrossRef]

5. Archer, E. Opinion: A Wolf in Sheep's Clothing. Available online: http://www.the-scientist.com/ ?articles.view/articleNo/37918/title/Opinion-A-Wolf-in-Sheep-s-Clothing/ (accessed on 28 July 2015).

6. Mitka, M. Do flawed data on caloric intake from NHANES present problems for researchers and policy makers? JAMA 2013, 310, 2137-2138. [CrossRef] [PubMed]

7. Ioannidis, J.P. Implausible results in human nutrition research. BMJ 2013, 347, f6698. [CrossRef] [PubMed]

8. Hébert, J.R.; Hurley, T.G.; Steck, S.E.; Miller, D.R.; Tabung, F.K.; Peterson, K.E.; Kushi, L.H.; Frongillo, E.A. Considering the value of dietary assessment data in informing nutrition-related health policy. Adv. Nutr. 2014, 5, 447-455. [CrossRef] [PubMed] 
9. Subar, A.F.; Freedman, L.S.; Tooze, J.A.; Kirkpatrick, S.I.; Boushey, C.; Neuhouser, M.L.; Thompson, F.E.; Potischman, N.; Guenther, P.M.; Tarasuk, V.; et al. Addressing current criticism regarding the value of self-report dietary data. J. Nutr. 2015, 145, 2639-2645. [CrossRef] [PubMed]

10. Freedman, L.S.; Commins, J.M.; Moler, J.E.; Arab, L.; Baer, D.J.; Kipnis, V.; Midthune, D.; Moshfegh, A.J.; Neuhouser, M.L.; Prentice, R.L.; et al. Pooled results from 5 validation studies of dietary self-report instruments using recovery biomarkers for energy and protein intake. Am. J. Epidemiol. 2014, 180, 172-188. [CrossRef] [PubMed]

11. Freedman, L.S.; Commins, J.M.; Moler, J.E.; Willett, W.; Tinker, L.F.; Subar, A.F.; Spiegelman, D.; Rhodes, D.; Potischman, N.; Neuhouser, M.L.; et al. Pooled results from 5 validation studies of dietary self-report instruments using recovery biomarkers for potassium and sodium intake. Am. J. Epidemiol. 2015, 181, 473-487. [CrossRef] [PubMed]

12. Carriquiry, A.L. Estimation of usual intake distributions of nutrients and foods. J. Nutr. 2003, 133, 601S-608S. [PubMed]

13. Dodd, K.W.; Guenther, P.M.; Freedman, L.S.; Subar, A.F.; Kipnis, V.; Midthune, D.; Tooze, J.A.; Krebs-Smith, S.M. Statistical methods for estimating usual intake of nutrients and foods: A review of the theory. J. Am. Diet. Assoc. 2006, 106, 1640-1650. [CrossRef] [PubMed]

14. Freedman, L.S.; Midthune, D.; Carroll, R.J.; Tasevska, N.; Schatzkin, A.; Mares, J.; Tinker, L.; Potischman, N.; Kipnis, V. Using regression calibration equations that combine self-reported intake and biomarker measures to obtain unbiased estimates and more powerful tests of dietary associations. Am. J. Epidemiol. 2011, 174, 1238-1245. [CrossRef] [PubMed]

15. Freedman, L.S.; Schatzkin, A.; Midthune, D.; Kipnis, V. Dealing with dietary measurement error in nutritional cohort studies. J. Natl. Cancer Inst. 2011, 103, 1086-1092. [CrossRef] [PubMed]

16. Mossavar-Rahmani, Y.; Shaw, P.A.; Wong, W.W.; Sotres-Alvarez, D.; Gellman, M.D.; Van Horn, L.; Stoutenberg, M.; Daviglus, M.L.; Wylie-Rosett, J.; Siega-Riz, A.M.; et al. Applying recovery biomarkers to calibrate self-report measures of energy and protein in the Hispanic Community Health Study/Study of Latinos. Am. J. Epidemiol. 2015, 181, 996-1007. [CrossRef] [PubMed]

17. Burrows, T.; Williams, R.; Rollo, M.; Wood, L.; Garg, M.L.; Jensen, M.; Collins, C.E. Plasma carotenoids levels as biomarkers of dietary carotenoid consumption: a systematic review of the validation studies. J. Nutr. Intermed. Metab. 2015, 2, 15-64. [CrossRef]

18. Asaad, G.; Sadegian, M.; Lau, R.; Xu, Y.; Soria-Contreras, D.C.; Bell, R.C.; Chan, C.B. The reliability and validity of the Perceived Dietary Adherence Questionnaire for people with Type 2 Diabetes. Nutrients 2015, 7, 5484-5496. [CrossRef] [PubMed]

19. Burrows, T.L.; Hutchesson, M.J.; Rollo, M.E.; Boggess, M.M.; Guest, M.; Collins, C.E. Fruit and vegetable intake assessed by food frequency questionnaire and plasma carotenoids: A validation study in adults. Nutrients 2015, 7, 3240-3251. [CrossRef] [PubMed]

20. Lai, J.S.; Attia, J.; McEvoy, M.; Hure, A.J. Biochemical validation of the Older Australian's Food Frequency Questionnaire Using carotenoids and vitamin E. Nutrients 2014, 6, 4906-4917. [CrossRef] [PubMed]

21. Aflague, T.F.; Boushey, C.J.; Leon Guerrero, R.T.; Ahmad, Z.; Kerr, D.A.; Delp, E.J. Feasibility and use of the Mobile Food Record for capturing eating occasions among children ages 3-10 years in Guam. Nutrients 2015, 7, 4403-4415. [CrossRef] [PubMed]

22. Rollo, M.E.; Ash, S.; Lyons-Wall, P.; Russell, A.W. Evaluation of a mobile phone image-based dietary assessment method in adults with Type 2 Diabetes. Nutrients 2015, 7, 4897-4910. [CrossRef] [PubMed]

23. Harray, A.J.; Boushey, C.J.; Pollard, C.M.; Delp, E.J.; Ahmad, Z.; Dhaliwal, S.S.; Mukhtar, S.A.; Kerr, D.A. A novel dietary assessment method to measure a healthy and sustainable diet using the Mobile Food Record: Protocol and methodology. Nutrients 2015, 7, 5375-5395. [CrossRef] [PubMed]

24. Carter, M.C.; Albar, S.A.; Morris, M.A.; Mulla, U.Z.; Hancock, N.; Evans, C.E.; Alwan, N.A.; Greenwood, D.C.; Hardie, L.J.; Frost, G.S.; et al. Development of a UK online 24-h dietary assessment tool: Myfood24. Nutrients 2015, 7, 4016-4032. [CrossRef] [PubMed]

25. Probst, Y.; Nguyen, D.T.; Tran, M.K.; Li, W. Dietary assessment on a mobile phone using image processing and pattern recognition techniques: Algorithm design and system prototyping. Nutrients 2015, 7, 6128-6138. [CrossRef] [PubMed]

26. Shatenstein, B.; Payette, H. Evaluation of the relative validity of the Short Diet Questionnaire for assessing usual consumption frequencies of selected nutrients and foods. Nutrients 2015, 7, 6362-6374. [CrossRef] [PubMed] 
27. Wright, J.; Sherriff, J.; Mamo, J.; Scott, J. Validity of two new brief instruments to estimate vegetable intake in adults. Nutrients 2015, 7, 6688-6699. [CrossRef] [PubMed]

28. Tasevska, N. Urinary sugars-A biomarker of total sugars intake. Nutrients 2015, 7, 5816-5833. [CrossRef] [PubMed]

29. Zheng, H.; Clausen, M.R.; Dalsgaard, T.K.; Bertram, H.C. Metabolomics to explore impact of dairy intake. Nutrients 2015, 7, 4875-4896. [CrossRef] [PubMed]

30. Kerr, D.A.; Wright, J.L.; Dhaliwal, S.S.; Boushey, C.J. Does an adolescent's accuracy of recall improve with a second 24-h dietary recall? Nutrients 2015, 7, 3557-3568. [CrossRef] [PubMed]

31. De Keyzer, W.; Bracke, T.; McNaughton, S.A.; Parnell, W.; Moshfegh, A.J.; Pereira, R.A.; Lee, H.S.; Van't Veer, P.; De Henauw, S.; Huybrechts, I. Cross-continental comparison of national food consumption survey methods-A narrative review. Nutrients 2015, 7, 3587-3620. [CrossRef] [PubMed]

32. Laureano, G.H.C.; Torman, V.B.L.; Crispim, S.P.; Dekkers, A.L.M.; Camey, S.A. Comparison of the ISU, NCI, MSM and SPADE methods for estimating usual intake: A simulation study of nutrients consumed daily. Nutrients 2016, 8, 166. [CrossRef] [PubMed]

33. Fulgoni, V.L.; Buckley, R.B. The contribution of fortified ready-to-eat cereal to vitamin and mineral intake in the U.S. population, NHANES 2007-2010. Nutrients 2015, 7, 3949-3958. [CrossRef] [PubMed]

34. Raatz, S.K.; Jahns, L.; Johnson, L.K.; Crosby, R.; Mitchell, J.E.; Crow, S.; Peterson, C.; Le Grange, D.; Wonderlich, S.A. Nutritional adequacy of dietary intake in women with anorexia nervosa. Nutrients 2015, 7, 3652-3665. [CrossRef] [PubMed]

35. Kaganov, B.; Caroli, M.; Mazur, A.; Singhal, A.; Vania, A. Suboptimal micronutrient intake among children in Europe. Nutrients 2015, 7, 3524-3535. [CrossRef] [PubMed]

36. Nishimuro, H.; Ohnisha, M.; Sato, M.; Ohnishi-Kametama, M.; Matsunaga, I.; Naito, S.; Ippoushi, K.; Oike, H.; Nagata, T.; Akasaka, H.; et al. Estimated daily intake and seasonal food sources of quercetin in Japan. Nutrients 2015, 7, 2345-2358. [CrossRef] [PubMed]

37. Choi, J.Y.; Kim, Y.N.; Cho, Y.O. Evaluation of riboflavin intakes and status of 20-64-year-old adults in South Korea. Nutrients 2015, 7, 253-264. [CrossRef] [PubMed]

38. Lentjes, M.A.H.; Welch, A.A.; Mulligan, A.A.; Luben, R.N.; Wareham, N.J.; Khaw, K.T. Cod liver oil supplement consumption and health: Cross-sectional results from the EPIC-Norfolk Cohort Study. Nutrients 2014, 6, 4320-4337. [CrossRef] [PubMed]

39. Ramage, S.M.; McCargar, L.J.; Berglund, C.; Harber, V.; Bell, R.C.; APrON Study Team. Assessment of pre-pregnancy dietary intake with a food frequency questionnaire in Alberta women. Nutrients 2015, 7, 6155-6166. [CrossRef] [PubMed]

40. Ferrari, A.; de Carvalho, A.M.; Steluti, J.; Teixeira, J.; Marchioni, D.M.L.; Aguiar, S., Jr. Folate and nutrients involved in the 1-carbon cycle in the pretreatment of patients for colorectal cancer. Nutrients 2015, 7, 4318-4335. [CrossRef] [PubMed]

41. Smith, K.L.; Kerr, D.A.; Howie, E.K.; Straker, L.M. Do overweight adolescents adhere to dietary intervention messages? Twelve-month detailed dietary outcomes from Curtin University's Activity, Food and Attitudes Program. Nutrients 2015, 7, 4363-4382. [CrossRef] [PubMed]

42. Ashby-Mitchell, K.; Peeters, A.; Anstey, K.J. Role of dietary pattern analysis in determining cognitive status in elderly Australian adults. Nutrients 2015, 7, 1052-1067. [CrossRef] [PubMed]

43. Collins, C.E.; Burrows, T.L.; Rollo, M.E.; Boggess, M.M.; Watson, J.F.; Guest, M.; Duncanson, K.; Pezdirc, K.; Hutchesson, M.J. The comparative validity and reproducibility of a diet quality index for adults: The Australian Recommended Food Score. Nutrients 2015, 7, 785-798. [CrossRef] [PubMed]

44. Daly, A.; Pollard, C.M.; Kerr, D.A.; Binns, C.W.; Phillips, M. Using short dietary questions to develop indicators of dietary behaviour for use in surveys exploring attitudinal and/or behavioural aspects of dietary choices. Nutrients 2015, 7, 6330-6345. [CrossRef] [PubMed]

(C) 2016 by the authors; licensee MDPI, Basel, Switzerland. This article is an open access article distributed under the terms and conditions of the Creative Commons by Attribution (CC-BY) license (http://creativecommons.org/licenses/by/4.0/). 